Journal of Social Sciences 3 (2): 52-59, 2007

ISSN 1549-3652

(C) 2007 Science Publications

\title{
Towards Two-tier Universalism? A Discussion of the Welfare Principle
}

\author{
Catharina Juul Kristensen \\ Department of Society and Globalisation, Building 25, Roskilde University, 4000 Roskilde, Denmark
}

\begin{abstract}
In this study the common political discourse on the 'challenge of immigration' to the Danish welfare state is turned on its head. Instead of focusing on the costs and difficulties of immigration, the focus is first upon the challenge that recent policies on immigration and integration constitute to the principle of universalism; and second upon the ability of the principle to encompass ethnic diversity. It is argued that a revision of the implicit normativity of the Danish welfare state is necessary in order to secure equality for all groups of society and positive selective measures based on recognition and status equality are proposed as a possible theoretical tool to further this.
\end{abstract}

Key words: The principle of universalism, the Danish welfare state, integration and immigration policies, theoretical alternatives

\section{INTRODUCTION}

Immigration and integration of ethnic minorities are now central political issues in Denmark. The political focus is primarily on non-Western immigrants and refugees. The group is frequently referred to as a challenge to the welfare state in the public debate. It is seen as a costly group, whose possibilities of economic self-sufficiency are limited. The political reaction has been a combination of protective and restraining measures. Immigration has been reduced and the policies concerning the welfare of the group tightened. Surprisingly, the challenge that the recent policies constitute to the key welfare principle universalism, is not ascribed the same political importance. A principle which, with is unique combination of equality, individuality and solidarity, constitutes the very basis of the success of the Danish welfare state.

The aim of this study was twofold. First, I explore the challenge that recent policies on immigration and integration constitute for the principle of universalism. Second, I explore the theoretical ability of the principle to include ethnic diversity. The empirical material is primarily constituted by legal material and government reports. These documents are analyzed on basis of a critical hermeneutic method. The analysis and discussion are based upon the included theoretical works on the principle of universalism. The findings finally form the basis of a short exploration of theoretical alternatives to the present politics that support and develop the rationale of the principle of universalism.
The article first includes a brief presentation of the challenge immigration and integration of non-Western minorities is seen to constitute. This section is followed by a presentation of the principle of universalism in a Danish context, focusing first on its history and second on its theoretical definition. Focus is then turned to Danish policy on integration of immigrants and their descendants, policies that cut across different welfare areas. Thereafter attention is directed at the flexibility of the principle universalism, an exploration leading to the final conclusion.

The challenge: Immigration and the non-Western minorities: Danish society has only recently changed from a relatively homogeneous to an ethnically diverse society. From the 1960s and onwards the picture of immigration has changed from immigration from neighboring countries to global immigration ${ }^{[1]}$. As a consequence of the economic upturn and a lack of labor in the late 1960s, immigrants were invited to Denmark to work. These 'guest workers' came primarily form Turkey and the former Yugoslavia and although in smaller numbers, Pakistan. After some years in the country many of the guest workers decided to settle and become reunified with their families. Due to high numbers of foreign job seekers and fears of a recession an 'immigration stop' was implemented in 1973. Thereafter only limited groups were granted residence permits to work $^{[2]}$. Family reunifications were, however, still possible and residence permits were given to new spouses. From the 1970s the majority of

Corresponding Author: Associate Professor, Dr. Catharina Juul Kristensen, Department of Society and Globalisation, Building 25, Roskilde University, 4000 Roskilde, Denmark 
the immigrants were thus either family-reunified, new spouses or refugees.

Today immigrants, refuges and their descendants constitute about 8 per cent of the population. The majority, 71 per cent, are from non-Western countries [3]. The largest non-Western minority originates from Turkey, but the group of non-Western citizens is of course diverse.

The ethnic minorities from non-Western countries are frequently referred to as a social problem. The group is in all its diversity seen as 'different and difficult to integrate'. Their education, experiences, values and norms are not seen as immediately applicable in Danish society ${ }^{[1]}$.

In the political world integration is largely measured by employment rate. That is the minorities' employment rate compared to that of the majority population. And this is indisputably low. In 2005 the employment rate for immigrants from non-Western countries were 46.1 per cent, against 60.2 per cent for immigrants from Western countries and 74.6 for ethnic Danes $^{[4]}$. When focusing on gender differences the picture worsens. Female immigrants from non-Western countries have the lowest unemployment rate of all, that is 39.4 per cent against 71.5 percent for women of Danish descent ${ }^{[4]}$.

As elaborated below the Danish welfare model is a vulnerable model. In contrast to a number of other Western welfare states, social benefits and services are tax financed and available to all citizens (i.e. Danish nationals and other legal residents). The social benefits are not, in other words, based on labor market participation, but citizenship. The political focus on labor marked participation is hence relevant. The problem is the conflation of integration and economic self-sufficiency and the possible neglect of the welfare needs and interest of the ethnic minority population.

Universalism in Danish welfare policy - the breakthrough and some key aspects: One of the main characteristics of the Danish welfare state is the comparatively high level of universality in social policy. The breakthrough of the principle is commonly identified as the Pension Reform of $1956^{[5]}$. This reform was followed by what is now seen as the core welfare services: social security, health and education for all.

The aim of universalism has historically been to secure the welfare of the country and its population, by securing basic needs, health and education. The aim has hence been to reduce social inequality and insecurity, first and foremost between the social classes, but other differences such as gender have also been included. Universalism, further, has prevention of social problems and preservation of dignity of those in need as some of its main ambitions.

In the context of this article two aspects of the Danish social welfare system are particularly important. First, the universal benefits are all tax financed. All citizens are thus able to make use of these on an equal footing, if and when necessary. The benefits are generally not contingent upon the citizens' contributions but, as mentioned, citizenship. The dependency on tax financing, or more generally the fusion of welfare and work, is both a strength and weakness of the Danish welfare model. The welfare state is consequently highly committed to but also dependent upon a high employment level. As an interrelated phenomenon the right and duty to work is a central norm in the Nordic countries. They are both 'strong work societies' and 'strong welfare states, $^{[6,7]}$.

Second, many social benefits are based on the principle of individuality. This type of benefits is given to the individual, irrespective of his or her marital/cohabitation status. Like the case of universalism the implementation of the principle of individuality is not complete. The principle of individuality constitutes, in my assessment, an important means to secure universal social rights of all citizens and can thus be said to supplement the principle of universalism. It is, however, continuously being challenged by another historically central element; the ambition of the state to secure and uphold the nuclear family.

Encirclement and definition of the principle: Although being a central and valued principle of Danish - and Nordic - social policy, the principle of universalism is only seldom defined. Instead its meaning is taken for granted. The principle is a 'wild' principle calling for contextual understandings. While general definitions may provide us with a theoretical infinitive, they do not necessarily reflect the concrete forms found in the different welfare states. The rationale, complexity and extent of the principles may in other words well vary between countries.

Goul Andersen's article 'The Universal welfare state under pressure - but what is universalism (author's translation) from 1999 constitutes one of the most thorough Nordic works in the field. There he defines universalism as 'rights- and citizenship based, general arrangements which secures extensive, 
adequate benefits (in cash and kind)'. 'Universalism is', he continues, 'synonymous with adequate benefits for all, but $[\ldots]$ these can be pure flat rate, means graded (most to the poor) and performance-graded (most to those who contributed the most $)^{[8]}$.

This narrow definition is based on a study of the purpose and ideal of the Nordic welfare states; where the purpose is identified as the strengthening of citizenship and democracy and the ideal behind the expansion as a wish to strengthen the citizens' autonomy through a strengthening of their resources. The ideal, Goul Andersen elaborates, is attempted reached through rights- and citizenship based benefits (a precondition, if all are to be treated with equal consideration and respect); and general and adequate welfare arrangements (which can be seen as a precondition for social equalization and a necessity if social and political marginalization is to be avoided). The extensive, adequate benefits are, furthermore, seen as a central precondition for the strengthening of the autonomy of the citizens ${ }^{[8]}$.

In line with Nordic mainstream welfare policy and research, Goul Andersen sees social inequality as structural inequality and the remedy as economic equalization. In general terms, the aim of the universal benefits is thus to reduce problems arising from this and not cultural or ethnic diversity.

The above definition is an ideal-typical definition based upon a positive reading of history. The fact that Goul Andersen identifies the Danish welfare model as 'strongly universal' on basis of the definition ${ }^{[8]}$, points, however, to its applicability - at least at the time of his work. Less comprehensive and complex forms of universalism are found outside the Nordic countries and within the area variations are of course present.

'Universalism is not, by itself alone, enough' ${ }^{[9]}$ : The benefits supplementing the fully universal benefits can best be understood when using Titmuss' work on positive, selective discrimination. In his terminology positive selectivism concerns those benefits that are offered to delimited groups on an equal basis. They are further aimed at meeting the needs of categories, groups and territorial areas, which are not met by the fully universal benefits. And in contrast to traditional (negative) selectivism, positive selectivism is 'based upon some structure of universalism'. Universalism, in turn,

"[...] provides a general system of values and a sense of community; socially approved agencies for clients, patients and consumers and also for the recruitment, training and deployment of staff at all levels; it sees welfare, not as a burden, but as a complementary and as an instrument of change and finally, it allows positive discriminatory services to be provided as rights for categories of people and for classes of need in terms of priority social areas and other impersonal classifications" ${ }^{\text {"[9] }}$.

Like universalism, positive selectivism has prevention and avoidance of stigma as some of its main ambitions. Furthermore, positive selective measures have the advantage of being sensitive to specific social differences.

When explored at this general theoretical but yet contextual level, the principle of universalism is based on a unique combination of equality, solidarity and individuality, aiming at securing social justice and social citizenship. Before elaborating upon the ability of the principle of universalism to include ethnic diversity, I explore how recent policies on immigration and integration challenge the principle of universalism, as it is defined above. The exploration is based on central parts of the policies.

Recent Danish integration policy: the Integration Act of 1998 laid the political line of Danish integration policy. This act, which constitutes the first Danish attempt to form coherent legislation concerning immigrants and refugees (aliens, 'foreigners' in the political discourse), stressed the importance of equality (full citizenship), economic independence (labor marked participation) and the need to be familiar with 'the fundamental norms and values of the Danish society' (cultural knowledge and assimilation) ${ }^{[10,11]}$. In spite of this threefold aim, the two latter have formed the centre of the concrete policy. Danish integration policy has thus a clear focus on labor market participation, economic independence, proficiency in Danish and knowledge of Danish culture. As part of the politics the duties of the ethnic minorities have been accentuated, social benefits have been reduced and measures have been taken to limit immigration. This priority, which was introduced by the Social Democratic led government in the late 1990s, has been tightened by the two subsequent Liberal-Conservative governments (in power since 2001).

As an odd contrast to the aim of facilitating equality, the Integration Act of 1998 included a three year Introduction benefit for refugees; a benefit which was significantly lower than the common social assistance (kontanthjælp). The formal political argument for the implementation of the Introduction 
benefit (introduktionsydelse) was that it would encourage the refugees to gain formal employment. But the incentive did not work. Instead the refugees were left without a sufficient disposal income. The Introduction benefit was not only in breach with decades of Danish refugee policy ${ }^{[12]}$. It also compromised the principle of universalism. The benefit was delimited to a negatively selected group, inadequate and potentially marginalizing.

The Introduction benefit was removed form the Integration Act in year 2000 - but only to be reintroduced in 2002 .

Start help, Integration benefit and the '24-year rule': In 2002 the newly elected Liberal-Conservative government introduced three contested measures; two fiscal benefits (the new Introduction benefit and Start help) and an age requirement for family reunification and marriage. Start help (starthjælp) applies to persons who have lived more than seven of the past eight years abroad. It thus includes Danish nationals, immigrants and refugees. Whereas Danish nationals are expected to seek formal employment or study when resettling in the country, persons belonging to one of the two latter groups are obliged to follow a three year integration program, during which they receive an Introduction benefit (same amount as Start help). After the threeyear period the immigrants and refugees are expected to seek full time employment or study. If unsuccessful they can apply for Start help.

In contrast to the first Introduction benefit, the two new benefits apply to a wider group of people. The benefits are also lower that the first Introduction benefit and can, finally, be effective for a period of seven years. The recipients are consequently left in an economically vulnerable position for a prolonged period of time. Although the two benefits apply to newcomers and returning nationals alike, they cannot be said to be universal. They are not only inadequate they also apply to an incomparable group. Returning nationals, who speak the language and are familiar with Danish society, have far better chances of gaining formal employment than immigrants and refugees.

The same year the government introduced what is commonly known as the '24-year rule'. This mandatory age requirement on reunification and marriage with nationals from Third countries (countries outside the Nordic countries and the EU), and officially aims at reducing the number of pro forma and forced marriages. Foreign nationals who wish to apply for family reunification with a spouse in Denmark and the spouse thus both have to be more than 24 years of age $^{[13]}$. The age requirement was introduced along with an extension of the obligation of economic selfsufficiency, a housing requirement and an extended affiliation requirement. As Grøndahl ${ }^{[14]}$ argues the combination of the requirements, and the political statements made by government representatives at the time of the introduction of the rule, do not point to an aim of protecting and assisting ethnic minority youth. Instead they point to a reduction of the number immigrants.

The tightened rules on family reunification and marriages do not comply with the criteria of universalism as they too only apply to citizens from a negatively selected group of countries, and as the rules appears to aim at a reduction of the rights and possibilities of this group.

Since the introduction of the 1998 Integration Act other policies, which affect the welfare of the ethnic minorities, have been implemented. One of the most important ones is the Labor Marked Reform of 2003, where a ceiling on social assistance was introduced after a six-month period of unemployment. This change applies to all long-term unemployed, including Danish nationals. However, critical analyses at the time showed that the reduction of benefits was most likely to affect unemployed with an ethnic minority background ${ }^{[15]}$. The ceiling on social assistance has been supplemented with further reductions of benefits for long term unemployed during the past couple of years. These reductions apply to all citizens alike, but are argued to disadvantage married couples. Many of these are from Third countries, as formal marriage is a precondition for (re)unification. The politics are - as the below section further illustrates - intertwined with politics on active social and labor marked policy.

'A new chance for everyone': One of the most recent policy initiatives is A new chance for everyone - the Danish Government's integration plan, passed in the Spring $2006^{[16]}$. The plan includes a broad range of issues concerning integration of the ethnic minority population, among these training and education, formal employment and prevention and combat of extremism and crime. Judging from the available information material on the Integration Plan and the interrelated program 'A New Chance' (Ny chance. For alle), that targets all long term unemployed, priority is given to the increase of ethnic minority citizens in formal employment and education. Particularly those from non-Western countries. The Integration Plan includes 
the Declaration on integration and active citizenship in Danish society and the Integration Contract.

According to the Integration Plan 'employment is the key to successful integration ${ }^{,[17]}$. And in countries like Denmark a key to employment is education. This twin focus of education and employment is in other words important. The trouble is, however, the combination of problems identified, the implicit image of the 'foreigner' and the sanctions for those who do not comply.

From July 2006 immigrants and refugees have been obliged to sign a 'Declaration on integration and active citizenship in Danish society' and draw up and sign an 'Integration Contract'. The target group only includes 'foreigners', not Danish nationals. Danish nationals who have returned after more than seven of the past eight years abroad are thus not included ${ }^{[18]}$. The aim of the Declaration is similar to that of the Integration Act, but the order of items has been changed, prioritizing the visibility of the values and expectations of Danish society. The aim being 'that the foreigner makes an effort to become integrated as an active and contributing citizen on an equal footing with other citizens ${ }^{,[19]}$. The Declaration and the Integration Contact are interrelated.

The Declaration contains seventeen different items, including compliance with and respect of democratic values, the responsibility to learn Danish and gain knowledge of Danish society, the responsibility of adults to be self-supporting, equal rights between men and women, laws prohibiting violence against ones' spouse and minor children and condemnation of terrorism and citizens' obligation to fight it ${ }^{[19]}$.

When reading the Declaration with an opposite sign we are left with an image of the target group as people who are prone not to know or accept, or perhaps even to violate the stated values. It enhances the image of particularly immigrants and refugees for nonWestern countries as 'different and therefore difficult to integrate' (note ${ }^{[1]}$ above). It further challenges the aim of the principle of universalism to preserve the dignity of the population and prevent stigmatization.

The aim of the Integration Contract is to formulate an individual plan for the mandatory three-year introduction program. The aim is further, that the 'foreigner' becomes formally employed and learns Danish as quickly as possible ${ }^{[19]}$. The governmental document both stipulates the duties of the 'foreigner' and the responsibility of the municipalities to secure the quality of the introduction program. Possible sanctions for the municipality are further included. The 'foreigner' can in other words be overruled or sanctioned if he or she is not cooperating.

The Declaration and the Contract are both effective for a minimum of seven years, when permanent residency can be obtained. They thus exceed the threeyear integration period. The immigrants and refugees seem, in sum, to be subjected to seven years of monitoring, before they can apply for permanent residency. Although the overall aim of the government's Integration Plan is to secure the economic independence and integration of the group, the combination of inadequate benefits, sanctions and the negative selection of the group, makes the initiatives non-universal. When relating the initiatives to Goul Andersen's definition, they do not secure extensive, adequate benefits and thus not social equalization and autonomy. The tone of the documents furthermore challenges the aim of preserving the dignity of citizens in need.

Danish policy concerning the integration and welfare of ethnic minority citizens is contradictory. While some of the fully universal benefits (e.g. free education and health care) and parts of the integration measures aim at assisting and empowering the ethnic minorities, others lead to marginalization or stigmatization. The overall rationale of the recent policy changes concerning integration of ethnic minority citizens points in the direction of assimilation. That is a demand to assimilate to the Danish work ethic and a more or less explicit ideal citizen.

The policies emphasize the economic basis of the Danish welfare state, the dependency on high employment levels; the duty to work; and what is characterized as Danish norms and values, e.g. democracy and gender equality. The policies thus contradict Goul Andersen's definition of the principle of universalism, whilst also accentuating the underlying ethic of work.

The policies on integration raise the question of 1) the future of the principle of universalism and 2) the formal status of the ethnic minority citizens. Is the Danish welfare state moving towards a more simple form of universalism and/or a two-tier society? Before elaborating these issues, it is time to explore the second problematic of the article: The theoretical ability of the principle of universalism to encompass diversity.

Universalism - an encompassing principle?: The question is now whether it is possible to provide universal benefits that meet needs and interests arising 
from ethnic diversity and thus counter some of the problems mentioned above. That is, if it is possible to provide universal measures that enable all citizens to be 'treated with equal consideration and respect' (note ${ }^{[6]}$ above), without resulting in demands of uniformity or assimilation. The Danish welfare state is, along with the other Nordic welfare states, renowned for its high level of gender equality. This achievement, the womenfriendly model, points to a model worth following. The comparatively high level of gender equality in Denmark shows the possibilities and success of universalism. Universalism has thus secured equal access to social benefits (supported by the principle of individuality), and the opportunity to combine work and care has been improved by the increase of public care facilities for children and the elderly. The welfare state has become comparatively women-friendly. The process of increased equality has furthermore been democratic and included both bottom-up and top-down initiatives ${ }^{[20,21 \text {, }}$ 22].

As part and parcel of this development Danish women now have one of the highest employment rates in the world, including mothers of infants ${ }^{[23]}$. Women have gained economic independence, and the dualearner family has become the norm.

The implicit citizen and the women-friendly welfare state: Within international feminist research it has been argued that universal welfare principles, such as the principle of universalism, are often based on an incomplete understanding of the citizen. British postwar social policy has, as an example, been criticized for being based on an implicit white, male, able-bodied, heterosexual citizen, living within a supportive nuclear family form ${ }^{[24,25]}$. The consequence has been neglect of differences based on gender and ethnicity, and of diversity.

In the light of the improvements of the rights and opportunities in Denmark, women are in general terms included in the notion of the implicit Danish citizen. The ideal citizen can thus be said to be a white, working, able-bodied, heterosexual man or woman living within a family. But as the above empirical material suggests, the notion does not include the ethnic minority population; at least not those citizens who cannot or do not meet the ethic of work.

At first sight the 'model' leading to increased gender equality seem to be a model worth following for the improvement of the welfare of the ethnic minority population. The results have benefited women (and men) and have been empowering and democratic in its form. The question is, however, whether the welfare needs and interests of the ethnic minorities are fully comparable with those of the majority population and intertwined whether the implicit rationale of the predominant understanding of equality is an ideal rationale for all.

To discuss last things first, the feminist discourse on women-friendliness is 'based upon the premise that women's labor market participation and economic independence is the key to equalization, ${ }^{[22]}$. The rationale tallies with the prevalent understanding of social equality as economic equality, and supports the strong work ethic of Danish society. The discourse further assumes a common interest of women ${ }^{[22]}-$ an interest that is not necessarily there. Following the women-friendliness model may consequently lend support to policies aiming at assimilation.

A possible solution?: A possible theoretical solution is the introduction of positive selective benefits $\left[\right.$ note $^{[9]}$ above] aimed at securing parity of participation and status equality of all groups of society, including of course the ethnic minority population. Learning from Nancy Fraser's work, recognition must be treated as a question of social status. Accordingly, a politics of recognition "means a politics aimed at overcoming subordination by establishing the misrecognized party as full member of society, capable of participating on a par with other members ${ }^{,[26]}$. Fraser's proposal has a number of similarities to the overall aim of universalism, but in contrast to the prevalent Nordic understanding of this, she stresses both redistribution and recognition.

An explicit inclusion of recognition in the discussion of the principle of universalism, allows for a revision of the implicit normativity of the principle and subsequently for the identification and negotiation of the welfare needs and interests of the ethnic minority population that may increase their ability to participate in society whilst upholding central elements of their ways of life. The aim of recognition is of course to counter misrecognition. That is, a situation where 'institutionalized patterns of cultural value constitute some actors as inferior, excluded, wholly other or simply invisible ${ }^{[26]}$. Consequently, policies aimed at integration of ethnic minority citizens should aim at a more diverse understanding of the ideal citizen and of the balance of central issues like work, family and 
political participation, leaving the population with status equality.

The introduction of positive selective benefits and services, aimed at reducing inequalities based on ethnic diversity, is a possible tool, and the democratic process of increasing gender equality a possible form. Within this format, integration would not imply assimilation, but integration based on dialogue and negotiation $\left(\right.$ note $\left.^{[27]}\right)$.

\section{CONCLUSION}

The challenge the recent policies on integration and the welfare of ethnic minority citizens constitute for the principle of universalism seems either point to a change of political priorities supporting a less comprehensive form of universalism, or to the introduction of a twotier society, where the working 'elite' enjoys full social citizenship and the non-assimilated, unemployed ethnic minorities (and nationals) do not. The movement is thus from a model based on equal benefits and services for all citizens, to a model based on a mixture of these and inadequate and potentially marginalizing benefits for 'the others'.

Although a reintroduction of benefits that meet the requirements of universal benefits as defined by Goul Andersen (i.e. 'rights and citizenship based, general arrangements which secures extensive, adequate benefits in cash and kind') is likely to improve the level of social equality, the implicit priority of economic equality and self-sufficiency of Danish welfare policy, potentially neglects welfare needs and interest based on cultural or ethnic differences. By implicitly presupposing and supporting a strong work ethic and dual earner families, other ways of life may, in the terminology of Fraser, be constituted as 'inferior' or 'simply invisible' [26]. In order better to encompass such differences the implicit normative core of the principle have to be reconceptualized and the perception of social equality expanded to include recognition on a par with redistribution. The quest is thus one of maintaining a central and valuable welfare principle, by positively adjusting it to the contemporary globalizing world.

\section{REFERENCES}

1. Emerek, R., 2003. Integration - eller inklusion? Den danske diskussion om integration. AMID Working Paper Series No. 31.
2. Bauer, T. et al., 2004. Immigration Policy and Danish and German Immigration. In: Migrants, Work and the Welfare State (Eds. T. Tranæs and K. F. Zimmermann.), pp: 31-73. University Press of Southern Denmark and the Rockwool Foundation Research Unit, Odense.

3. Indenrigsministeriet, 2006. Indvandrere og efterkommere fra vestlige og ikke-vestlige lande pr. 1. januar 2005. Indenrigsministeriets udlændingedatabase i Danmarks Statistik, BEF13 and Danmarks Statistikbank, www. Statistik banken. dk, BEF3.

4. Statistikbanken, 2006. Erhvervs- og beskæftigelsesfrekvenser efter køn, alder, område, beregning, herkomst og tid. www.statistikbanken.dk/statbank5a/.

5. Christiansen, N.F. and K. Petersen 2001. The Dynamics of Social Solidarity: The Danish Welfare State, 1900-2000. Scand. J. History, 26: 177-196.

6. Esping-Andersen, G., 1990. The Three Worlds of Welfare Capitalism. Polity Press, Cambridge.

7. Kildal, N. and S. Kuhnle 2005. The Nordic welfare model and the idea of universalism. In: Normative Foundations of the Welfare State. The Nordic experience. (Eds. N. Kildal \& S. Kuhnle), pp: 1333. Routledge, London.

8. Goul, A.J., 1999. Den universelle velfærdsstat er under pres - men hvad er universalisme? GRUS, 56/57: 40-62.

9. Titmuss, R., 1987 [1967]. Welfare State and Welfare Society. In: The Philosophy of Welfare. Selected Writings of Richard M. Titmuss. (Eds. B. Abel-Smith \& K. Titmuss), pp: 141-156. Allen \& Unwin, London.

10. Lov om integration af udlændinge i Danmark. LOV nr. 474 af 01.07. 1998.

11. Ejrnæs, M., 2001. Integrationsloven - en case, der illustrerer etniske minoriteters usikre medborgerstatus. AMID Working Paper Series. No. 1.

12. Ejrnæs, M., 2004. Flygtninge og indvandreres forsørgelsesydelser - en eksemplarisk case. In: H. Thelle \& I. E. Koch (Eds.): Sociale menneskerettigheder. København: Akademisk Forlag, pp: 172-13.

13. Danish Immigration Service, 2006. Rules applying to family reunification with a spouse in Denmark. 
14. Grøndahl, M., 2006. Familiesammenføring. In: Når du strammer garnet - et opgør med mobning af mindretal og ansvarsløs asylpolitik (Eds. C. Fenger-Grøn et al.), pp: 184-211. Aarhus Universitetsforlag, Århus.

15. Ejrnæs, M. and M. Skytte, 2004. Etniske minoriteter og socialpolitik. In: Socialpolitik (Eds J. E. Larsen and I. H. Møller.), pp: 249-262. Hans Reitzels Forlag, København.

16. Beskæftigelsesministeriet, 2005. Sammenfatning: En ny chance til alle - regeringens integrationsplan. www.bm.dk

17. Ministry of Refugee, Immigration and Integration Affairs 2005. A new chance for everyone - the Danish Government's integration plan. May.

18. Integrationsministeriet, 2005. Personkreds med pligt efter integrationsloven at indgå en integrationskontrakt. Notat af 27.09.05, Integrationskontoret.

19. Ministeriet for Flygtninge, Indvandrere og Integration 2006. Integrationskontrakten og erklæring om integration og aktivt medborgerskab i det danske samfund. Informationsmateriale til kommunerne. Marts.

20. Hernes, H.M., 1987. Welfare State and Woman Power. Essays in State Feminism. Norwegian University Press, Oslo.
21. Anttonen, A., 2002. Universalism and social policy: a Nordic-feminist revaluation. NORA, 10: 71-80.

22. Siim, B. and A. Borchorst, 2005. The womanfriendly welfare state revisited. In: Normative Foundations of the Welfare State. The Nordic experience. (Eds. N. Kildal \& S. Kuhnle), pp: $97-$ 111. Routledge, London.

23. Abrahamson, P., T. Boje and B. Greve, 2005. Welfare and families in Europe. Ashgate, Aldershot.

24. Williams, F., 1992. Somewhere over the rainbow: universality and diversity in social policy. Social Policy Review, 4: 200-219.

25. Lister, R., 1998. Citizenship and Difference. Towards a Differentiated Universalism. Eur. J. Social Theory, 1: 71-90.

26. Fraser, N., 2001: Recognition without Ethics? Theory, Culture \& Society, 18: 21-42.

27. Kristensen, C.J., 1997. Gensidig integration ansatser til en teoretisk tilgang til differentieret social integration. In: Sammenbrud eller sammenhold... (Eds. T. J. Hegland et al.) pp: 29-37. Akademisk Forlag, København. 